\title{
Latent effects of larval food limitation on filtration rate, carbon assimilation and growth in juvenile gastropod Crepidula onyx
}

\author{
J. M. Y. Chiu, T. Y. T. Ng, W. X. Wang, V. Thiyagarajan, P. Y. Qian* \\ Department of Biology/Coastal Marine Laboratory, The Hong Kong University of Science and Technology, Clearwater Bay, \\ Kowloon, Hong Kong SAR
}

\begin{abstract}
In this study we examined the latent effects of larval food limitation on the performance of juvenile Crepidula onyx under both laboratory and field conditions, and the possible mechanisms through which these latent effects were mediated. Larvae were reared at either high or low food concentrations before they were induced to metamorphose. Feeding larvae at a low food concentration reduced the size, total organic content and energy reserves of newly metamorphosed juveniles. Juvenile growth (measured as increases in shell length and total organic carbon content) and survival were then followed for 3 to $17 \mathrm{~d}$. Under both laboratory and field conditions, we found that growth was compromised for the juveniles that developed from larvae fed at the low food concentration. However, feeding larvae at the low food concentration reduced juvenile survival only under laboratory conditions, not in the field. Thus, juvenile habitat conditions seem to have altered the latent effects of larval food limitation on juvenile survival. Our results also suggest that the filtration rate of juveniles developed from larvae fed at the low food concentration was significantly reduced. Followup experiments showed that the larval food concentration did not affect carbon assimilation efficiency of juveniles, and that the latent effects of limited larval food conditions did not simply reflect the consequence of reduced energy reserves or size at metamorphosis. Poor food-collecting performance of juveniles was at least partially responsible for the observed latent effects of larval food limitation on juvenile growth.
\end{abstract}

KEY WORDS: Crepidula onyx · Food concentration · Gastropod · Juvenile growth · Juvenile survival · Larvae $\cdot$ Latent effects

\section{INTRODUCTION}

Many marine invertebrates have a pelagic larval stage specialised for dispersal and the colonisation of new habitats (Young 2002). After going through a certain developmental period, larvae metamorphose into benthic juveniles, marking a complete change in morphology, ecology and physiology (Young 2002). Indeed, for many years, various studies have investigated the life cycle in the context of processes such as the transport of larvae (Marsh et al. 1999), larval growth and development (Zhao et al. 2003), substratum preference for metamorphosis (Chiu et al. 2007), and juvenile or adult growth and mortality (Gosselin \& Qian 1997, Marshall et al. 2003) in order to understand population dynamics. But the link between one stage and another in the life cycle has usually been neglected.

Over the past decade or so, there has been a growing interest in the studies of latent effects (Pechenik 2006), which have also been called 'carryover effects' (e.g. Marshall et al. 2003), referring to effects resulting from conditions experienced in early development, such as the larval stage, that are expressed only in juvenile or adult stages. Collectively, these studies have suggested that latent effects of larval experiences such 
as delayed metamorphosis, nutritional stress, salinity stress and exposure to sub-lethal concentrations of pollutants may affect juvenile and even adult performance in marine invertebrates, insects, fish and amphibians (reviewed by Pechenik 2006).

Previous studies have shown that larval food limitation or short-term starvation can reduce larval growth rate (polychaetes: Qian \& Chia 1993; bivalves: His \& Seaman 1992; crustaceans: Qiu \& Qian 1997; gastropods: Zhao et al. 2003), increase larval mortality (crustaceans: Thorson 1950; bivalves: His \& Seaman 1992; gastropods: Zhao et al. 2003), reduce metamorphic success (echinoderms: Eckert 1995) and decrease larval size and energy content at metamorphosis (echinoderms: Hart \& Strathmann 1994; polychaetes: McEdward \& Qian 2001; gastropods: Pechenik et al. 2002; bivalves: Phillips 2002, 2004; crustaceans: Thiyagarajan et al. 2003). Although nutritional stress occurring early in development reduced juvenile growth, development and/or survival rates of sea urchin Strongylocentrotus purpuratus (Miller \& Emlet 1999), mussel Mytilus galloprovincialis (Phillips 2002), barnacles Balanus amphitrite (Thiyagarajan et al. 2003) and B. glandula (Emlet \& Sadro 2006), and gastropod Crepidula fornicata (Pechenik et al. 2002), larval starvation had no apparent effect on juvenile growth for the polychaete worm Hydroides elegans (Qian \& Pechenik 1998).

The mechanisms through which latent effects are mediated have rarely been studied. The limited data available suggest that abnormal development and food-collecting performance of juvenile gills might account for the reduced juvenile growth rates documented for juveniles developing from larvae that had experienced food limitation in Crepidula fornicata (Pechenik et al. 2002); members of the genus Crepidula, including C. fornicata and C. onyx, filter feed (authors' pers. obs.). Similarly, reduced growth rates in the bryozoan Bugula neritina (Wendt 1998) and the colonial ascidian Diplosoma listerianum (Marshall et al. 2003) were apparently caused by the smaller juvenile feeding structure. Although Pechenik (2006) proposed that reduced juvenile growth rates might also reflect reduced ability to digest or assimilate food, altered nutritional requirements for maximum growth, or increased rates of metabolic expenditure, these hypotheses have not been tested.

In the present study, we first examined the latent effects of larval food limitation on growth and survival of juvenile Crepidula onyx under both laboratory and field conditions. We also investigated whether juveniles of $C$. onyx that developed from larvae fed at a low food concentration have a reduced ability to obtain and assimilate food. An alternative hypothesis is that a reduced juvenile growth rate might be merely a conse- quence of small juveniles having a low growth rate (Marshall \& Keough 2004). It may take small juveniles longer to reach the size and growth rate of those juveniles that are larger at metamorphosis (Phillips 2002). Therefore, we compared the growth curves of juveniles that had different larval food concentrations after the small juveniles (reared as larvae at a low food concentration, hereafter: Low treatment) had reached the size of the juveniles that were larger at metamorphosis (reared as larvae at a high food concentration, hereafter: High treatment).

\section{MATERIALS AND METHODS}

Obtaining and rearing larvae. Adults were collected from the low intertidal zone in Victoria Harbour, Hong Kong, and held in an aquarium on a diet of naked flagellate Isochrysis galbana (Tahitian strain, clone TISO). Larvae released from these adults were randomly transferred to 6 glass jars at a density of approximately 1 larva $\mathrm{ml}^{-1}$. Larvae in 3 of the glass jars fed on a diet of I. galbana at a concentration of $1 \times$ $10^{4}$ cells ml ${ }^{-1}$ (Low treatment), whereas larvae in the remaining 3 jars fed on $I$. galbana at a concentration of $2 \times 10^{5}$ cells ml $^{-1}$ (High treatment). The concentration of $1 \times 10^{4}$ cells ml ${ }^{-1}$ of $I$. galbana was the minimum required to sustain Crepidula onyx larval growth and development, but at a rate significantly slower than that of $1.8 \times 10^{5}$ cells ml ${ }^{-1}$ shown to support $C$. onyx growth (Zhao et al. 2003). New I. galbana cells were added twice a day to replenish those consumed by the larvae. Seawater was changed and jars were cleaned every other day. Membrane-filtered (pore size: $0.22 \mu \mathrm{m}$ ) natural seawater (salinity: $34 \mathrm{psu}$ ) was used in all larval rearing and experimental procedures. A different larval batch was used in each experiment. C. onyx adults, larvae and juveniles were maintained at $24^{\circ} \mathrm{C}$.

Larvae were sub-sampled daily from each of the glass jars, and their competence for metamorphosis was assessed by checking for the occurrence of shell 'brims' and by a $6 \mathrm{~h}$ bioassay with seawater whose $\mathrm{K}^{+}$ concentration had been elevated by $15 \mathrm{mM}$ (Pechenik et al. 2002). Metamorphosis was defined as permanent loss of larval swimming ability due to a significant reduction or total loss of velar lobes (Pechenik et al. 2002). When $>50 \%$ of the sub-sampled larvae were competent, the remaining larvae from the respective food treatment were combined and redistributed among plastic Petri dishes (FALCON No. 1006). The larvae were then induced to metamorphose in seawater whose $\mathrm{K}^{+}$concentration had been elevated by $15 \mathrm{mM}$. Larvae that did not metamorphose within $24 \mathrm{~h}$ were discarded. During this $24 \mathrm{~h}$ period, the larvae were provided with Isochrysis galbana at a concentra- 
tion of $1 \times 10^{4}$ cells ml ${ }^{-1}$ (Low treatment) or $2 \times 10^{5}$ cells $\mathrm{ml}^{-1}$ (High treatment).

Expt I-effects on juvenile carbon assimilation, growth and survival in the laboratory. This experiment was conducted in June 2006. Most of the larvae sub-sampled from the High and Low treatments were competent by 6 and $12 \mathrm{~d}$ after hatching, respectively. For each food treatment, 20 larvae were first pipetted into each of 12 Petri dishes, and induced to metamorphose, whilst the remaining larvae were used to determine carbon assimilation efficiency (see subsection 'Carbon assimilation'). After $24 \mathrm{~h}$, the newly metamorphosed juveniles in the 6 Petri dishes were first measured for shell length at $50 \times$ using a dissecting microscope equipped with an ocular micrometer and were then used to determine total organic carbon and lipid content (see following sub-section). Juveniles in the remaining 6 Petri dishes were reared for another $6 \mathrm{~d}$ on a diet of Isochrysis galbana at $2 \times 10^{5} \mathrm{cells} \mathrm{ml}^{-1}$. Seawater was changed, new I. galbana cells were added, and dead juveniles were removed daily. At $6 \mathrm{~d}$ post-metamorphosis, the number of surviving juveniles in each Petri dish was determined, and the shell lengths and total organic carbon content of these juveniles were measured.

Total organic carbon and lipid content: Groups of juveniles from each of the 6 Petri dishes were rinsed with distilled water. Half of the juvenile groups were collected into tin capsules, dried at $110^{\circ} \mathrm{C}$ for $24 \mathrm{~h}$, and then analysed for total organic carbon content using a PerkinElmer 2400 Series II CHNS/O Analyser, while the other half were lysed by ultrasonic pulses (Branson Sonifier 450) for 2 min; lipids from these juveniles were subsequently extracted and quantified by sulphuric acid charring (Mann \& Gallager 1985), with tripalmitin as the standard.

Carbon assimilation: Assimilation of carbon from Isochrysis galbana by newly metamorphosed juveniles was determined using radiotracer ${ }^{14} \mathrm{C}$ (He \& Wang 2006). I. galbana cells were collected on $1 \mu \mathrm{m}$ polycarbonate membranes, and re-suspended into $100 \mathrm{ml}$ seawater with $f / 2$ culture medium. Radiotracer ${ }^{14} \mathrm{C}$ (555 kBq, $\mathrm{NaH}^{14} \mathrm{CO}_{3}$ ) was added to the medium, and the I. galbana cells were grown for $4 \mathrm{~d}$ to attain uniform labelling. Larvae from the respective food treatments were induced to metamorphose into juveniles on plastic Petri dishes. These juveniles were allowed to empty their guts in seawater $2 \mathrm{~h}$ before radioactive feeding. There were 4 replicates and 5 time point measurements (after 0, 2, 4, 9 and $24 \mathrm{~h}$ of depuration). In each replicate beaker, there were 5 Petri dishes each containing 10 to 38 juveniles, and $500 \mathrm{ml}$ of radiolabelled $I$. galbana suspension at a concentration of $2 \times$ $10^{5}$ cells ml${ }^{-1}$. After $1 \mathrm{~h}$ of feeding on radiolabelled cells ( $0 \mathrm{~h}$ of depuration), 1 Petri dish from each replicate beaker was retrieved, and all the juveniles in the Petri dish were rinsed with distilled water and transferred to a vial containing $2 \mathrm{ml}$ of $1 \mathrm{M} \mathrm{NaOH}$. Other juveniles were allowed to depurate in the presence of non-radiolabelled I. galbana cells at a concentration of $2 \times 10^{5}$ cells ml ${ }^{-1}$. After 2, 4, 9 and $24 \mathrm{~h}$ of depuration, 1 Petri dish from each beaker was retrieved and processed as were those at $0 \mathrm{~h}$. Seawater was changed and nonradiolabelled I. galbana cells were added at 0 and $9 \mathrm{~h}$ of depuration to facilitate depuration and allow continuous feeding by the juveniles. When all juveniles were recovered, they were lysed by ultrasonic pulses (Branson Sonifier 450) for 2 min and then incubated in a water bath at $80^{\circ} \mathrm{C}$ for $2 \mathrm{~h}$ to dissolve the tissue. The samples were then added to $6 \mathrm{ml}$ scintillation cocktails (Wallac OptiPhase 'HiSafe' 3) and incubated in the dark for another $12 \mathrm{~h}$ before the ${ }^{14} \mathrm{C}$ activities were measured using a Wallac WinSpectral 1414 liquid scintillation counter (Perkin Elmer). Assimilation efficiency (\%) was calculated as the percentage of ingested ${ }^{14} \mathrm{C}$ retained in the juveniles after $24 \mathrm{~h}$ of depuration. An assumption basic to this calculation was that ${ }^{14} \mathrm{C}$ that has been assimilated and then lost as respired ${ }^{14} \mathrm{CO}_{2}$ was negligible. Pechenik (1979) suggested that a significant portion of unassimilated carbon produced by Crepidula fornicata larvae was excreted or leaked rather than respired.

Expt II-effects on juvenile growth and survival in the field. This outplant experiment was conducted in March 2006 at Peng Chau (22 $\left.15^{\prime} \mathrm{N}, 114^{\circ} 1^{\prime} \mathrm{E}\right)$, Victoria Harbour Star Ferry pier in Central $\left(22^{\circ} 17^{\prime} \mathrm{N}\right.$, $114^{\circ} 10^{\prime}$ E) and Port Shelter (22 $19^{\prime} \mathrm{N}, 114^{\circ} 16^{\prime}$ E) Hong Kong; a map displaying these sites can be found in Chiu et al. (2007). In the $12 \mathrm{~d}$ of the outplant period, water temperature ranged from 19 to $20^{\circ} \mathrm{C}$ and salinity ranged from 32 to 34 psu across the field sites. At $7 \mathrm{~d}$ after hatching, 30 to 33 larvae from the High treatment were pipetted into each of the 9 Petri dishes and induced to metamorphose. Newly metamorphosed juveniles were circled with a marker on the Petri dishes, and the shell lengths of 20 ind. were measured. The Petri dishes were then immersed in seawater and outplanted to the field sites. Three dishes, each attached to a different cable hanging from a pier, were deployed in the low intertidal zone at Peng Chau, Victoria Harbour and Port Shelter, respectively. After $6 \mathrm{~d}$, we collected all the Petri dishes, immersed them in seawater and transported them back to the laboratory in closed aquaria. The number of recovered juveniles in each Petri dish was determined, and their shell lengths were measured.

At $14 \mathrm{~d}$ after hatching, 20 to 30 larvae from the Low treatment were pipetted into each of 9 Petri dishes and handled in the same way as were those from the High treatment. The Petri dishes were then deployed at the 
field sites for $6 \mathrm{~d}$. Because larvae from the Low treatment developed metamorphic competence $7 \mathrm{~d}$ after those from the High treatment, the field outplants of the juveniles from the 2 treatments were separated by $7 \mathrm{~d}$.

Expt III-juvenile filtration rate and growth curves. This experiment was conducted in August 2006. At $7 \mathrm{~d}$ after hatching, 42 larvae from the High treatment were pipetted into each of 3 Petri dishes and induced to metamorphose into juveniles. Juveniles were reared for another $12 \mathrm{~d}$ and fed Isochrysis galbana at a concentration of $2 \times 10^{5}$ cells $\mathrm{ml}^{-1}$. Seawater was changed, new I. galbana cells were added, and dead juveniles were removed daily. At 1, 3, 6 and 12 d post-metamorphosis, juvenile shell length and filtration rate were measured, as described below. At $15 \mathrm{~d}$ after hatching, the larvae from the Low treatment were re-distributed, induced to metamorphose, and handled in the same way as were those from the High treatment. Juvenile shell lengths and filtration rates were measured at 3, 6, 12 and 17 d post-metamorphosis. These juveniles were reared for $17 \mathrm{~d}$ instead of $12 \mathrm{~d}$ to reach the size of the $12 \mathrm{~d}$ old juveniles from the High treatment.

Filtration rates were determined by monitoring decreases in the concentration of Isochrysis galbana over time using a Beckman Z2 Coulter particle count and size analyser. There were 3 replicates for each measurement. A Petri dish containing a group of juveniles was placed in $100 \mathrm{ml}$ of $I$. galbana suspension at a concentration of $2 \times 10^{5}$ cells ml $\mathrm{ml}^{-1}$ in each of 3 replicate beakers, and maintained in the dark at $24^{\circ} \mathrm{C}$ for $5 \mathrm{~h}$. The suspension was gently stirred every $30 \mathrm{~min}$, and $I$. galbana concentration was measured at hourly intervals. The control was a beaker containing only I. galbana suspension and no juveniles; the $I$. galbana concentration did not change significantly in the control beaker during the feeding period. The mean filtration rate per juvenile was therefore calculated from the exponential decrease in I. galbana concentration during the $5 \mathrm{~h}$ feeding period and expressed as millilitres of water filtered per hour.

Statistical analysis. Percentage data were arcsine transformed before analysis (Zar 1999). The normality and homogeneity of the data were checked with the Shapiro-Wilk's $W$-test and Cochran's test, respectively. In Expt I, we used 1-way analysis of variance (ANOVA) to examine the effects of larval food treatment on shell length, total organic carbon and lipid content, as well as assimilation efficiency of newly metamorphosed juveniles, percent survival and increase in shell length, and total organic carbon content of juveniles $6 \mathrm{~d}$ after metamorphosis. In Expt II, we used 2-way ANOVA to examine the effects of field site, larval food treatment and their interaction on percent juvenile survival and increase in juvenile shell length.
In Expt III, we described juvenile growth rates and the relationship between shell length and filtration rate using linear regression (best-fit regression curve) analysis. We used $t$-tests to compare the shell lengths and filtration rates of juveniles that had received dif-
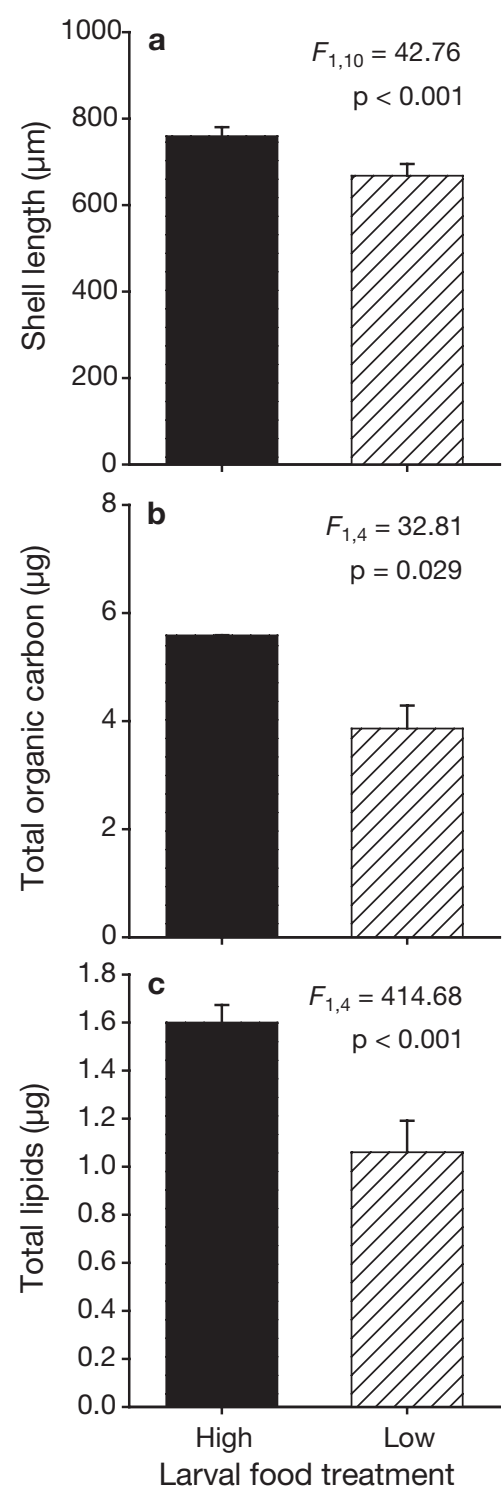

Fig. 1. Crepidula onyx. Expt I: (a) shell length, (b) total organic carbon and (c) lipid content of newly metamorphosed juveniles that developed from larvae that were reared at a high or low food concentration. High treatment: larvae were fed Isochrysis galbana at a concentration of $2 \times 10^{5}$ cells ml- $\mathrm{ml}^{-1}$. Low treatment: larvae were fed $I$. galbana at a concentration of $1 \times 10^{4}$ cells ml ${ }^{-1}$. Data are mean $(+\mathrm{SD})$ of 6 replicate dishes (a), or 3 replicate dishes $(b, c)$. Each replicate dish had a group of 9 to 20 juveniles. In (a), shell lengths of all juveniles in replicate dishes were first pooled together. One-way ANOVA results showing the effects of larval food treatment (fixed factor: Low and High) on shell length and total organic carbon and lipid contents of newly metamorphosed juveniles are shown in respective panels 
ferent food treatments as larvae. The slopes of the regression lines for juveniles from the High and Low treatments were compared using ANCOVA (Zar 1999). The data presented in the figures were not transformed.

\section{RESULTS}

\section{Expt I-reduced juvenile growth and survival in the laboratory}

The larval food treatment had a significant effect on mean shell length and total organic carbon and lipid content of newly metamorphosed Crepidula onyx juveniles (Fig. 1). The newly metamorphosed juveniles that developed from larvae fed with the Low treatment had a mean shell length of $668 \mu \mathrm{m}$, which was significantly lower than that of $759 \mu \mathrm{m}$ for newly metamorphosed juveniles developed from larvae fed with the High treatment (Fig. 1a). Moreover, these newly metamorphosed juveniles from the Low treatment had mean total organic carbon and lipid contents that were only $60 \%$ of those from individuals from the High treatment (Fig. 1b,c).

The loss of carbon by juveniles following $1 \mathrm{~h}$ feeding on radiolabelled Isochrysis galbana is shown in Fig. 2. ${ }^{14} \mathrm{C}$ radioactivity declined abruptly in juveniles as the gut emptied during the first 5 to $10 \mathrm{~h}$ of depuration in non-radioactive food suspension. This was followed by a gradual decline in radioactivity after the gut was totally emptied of the radiolabelled I. galbana. Mean $( \pm \mathrm{SD})$ percent carbon retained in the juvenile body at $24 \mathrm{~h}$ in the High and Low treatments was nearly identical (68 \pm 11 and $69 \pm 17 \%$, respectively). Assimilation efficiency was not affected by the larval food treatment either ( $p=0.622,1$-way ANOVA).

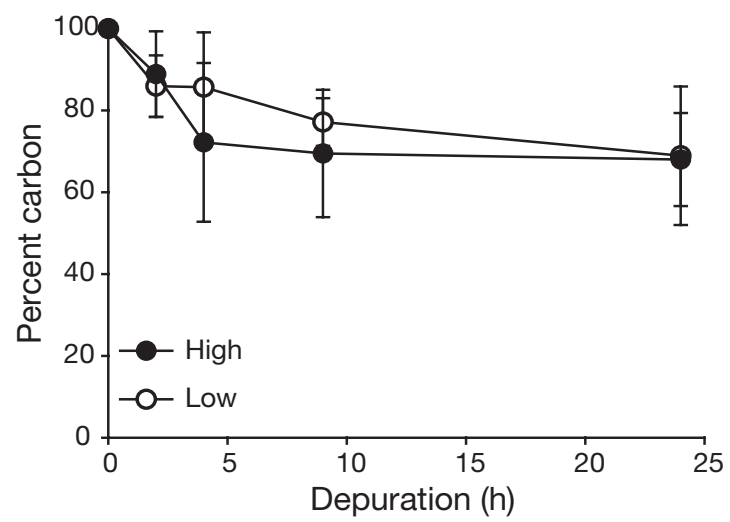

Fig. 2. Crepidula onyx. Expt I: retention of carbon by juveniles that developed from larvae that were reared at a high or low food concentration (High and Low, respectively). Data are mean $( \pm \mathrm{SD})$ of 4 replicates, each with a group of 10 to 38 juveniles derived from a different replicate beaker
For juveniles feeding for $6 \mathrm{~d}$ on Isochrysis galbana at a concentration of $2 \times 10^{5}$ cells $\mathrm{ml}^{-1}$, the larval food treatment still had significant effects on percent survival, shell length and total organic carbon content of juveniles (Fig. 3). The juveniles derived from larvae that had been fed with the Low treatment had lower survival (Fig. 3a). Similarly, their shell length and total carbon content only increased by $251 \mu \mathrm{m}$ and $4.6 \mu \mathrm{g}$, respectively, in contrast to increases of $399 \mu \mathrm{m}$ and 6.4 $\mu \mathrm{g}$, respectively, for those that had been reared with the High treatment as larvae (Fig. 3b,c).

\section{Expt II-reduced juvenile growth in the field}

In this experiment, the newly metamorphosed juveniles from the Low treatment had a mean $( \pm \mathrm{SD})$ shell length of $573 \pm 53 \mu \mathrm{m}(\mathrm{n}=20)$, which was significantly lower than the mean $( \pm \mathrm{SD})$ shell length of $703 \pm 52 \mu \mathrm{m}$ $(\mathrm{n}=20)$ for juveniles from the High treatment $(\mathrm{p}<$ 0.001, 1-way ANOVA). After being in the field for $6 \mathrm{~d}$, only 34 to $57 \%$ of juveniles were recovered (Fig. 4a). Neither the field site nor the larval food treatment had a significant effect on the percent juvenile survival (Table 1).

The increase in juvenile shell length was significantly affected by the larval food treatment, but not by the field site (Table 1). The juveniles developed from larvae that were reared with the High treatment increased their shell length by an average of 332, 333 and $312 \mu \mathrm{m}$ at Peng Chau, Victoria Harbour and Port Shelter, respectively. In contrast, the juveniles from larvae that were reared with the Low treatment increased their shell length by an average of only 146, 193 and $110 \mu \mathrm{m}$ at Peng Chau, Victoria Harbour and Port Shelter, respectively (Fig. 4b).

\section{Expt III-limiting larval food reduced juvenile filtration rate}

The larval food treatment significantly affected the increase in juvenile shell length at $12 \mathrm{~d}$ post-metamorphosis; the juveniles developed from larvae fed with the Low treatment increased their shell lengths (mean $\pm \mathrm{SD})$ by $497 \pm 48 \mu \mathrm{m}(\mathrm{n}=3$, each with a group of 10 juveniles) in $12 \mathrm{~d}$, which was only two-thirds that of $771 \pm 45 \mu \mathrm{m}(\mathrm{n}=3$, each with a group of 10 juveniles) of the juveniles developed from larvae fed with the High treatment $\left(t_{4}=7.24, \mathrm{p}<0.002\right)$.

At $3 \mathrm{~d}$ post-metamorphosis, the juveniles from the Low treatment had reached a mean $( \pm \mathrm{SD})$ size of $786 \pm$ $27 \mu \mathrm{m}$ ( $\mathrm{n}=3$, each with a group of 10 juveniles), which was not significantly different from a mean $( \pm$ SD) size of juveniles from the High treatment at $1 \mathrm{~d}$ post-meta- 
morphosis of $783 \pm 37 \mu \mathrm{m}(\mathrm{n}=3$, each with a group of 10 juveniles) ( $t_{4}=0.106, \mathrm{p}=0.921$ ). Subsequently, we examined the growth curves of juveniles from the Low treatment from $3 \mathrm{~d}$ post-metamorphosis onwards, and that of the juveniles from the High treatment from $1 \mathrm{~d}$ post-metamorphosis onwards (Fig. 5a). Positive linear relationships between juvenile shell length and age
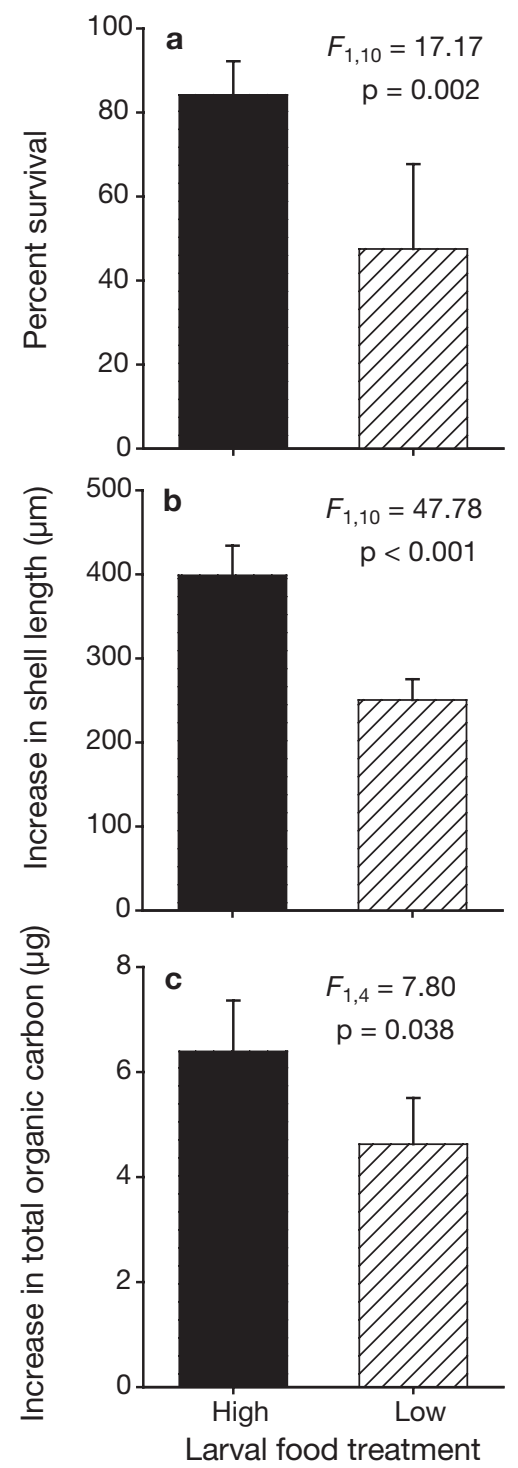

Fig. 3. Crepidula onyx. Expt I: (a) percent survival and increase in (b) shell length and (c) total organic carbon content of juveniles that developed from larvae from High or Low treatments, feeding for $6 \mathrm{~d}$ after metamorphosis on Isochrysis galbana at a concentration of $2 \times 10^{5} \mathrm{cells} \mathrm{ml}^{-1}$. Data are mean $(+\mathrm{SD})$ of 6 replicate dishes $(\mathrm{a}, \mathrm{b})$, or 3 replicate dishes $(\mathrm{c})$. Each replicate dish had a group of 6 to 19 juveniles. In (b), shell lengths of all juveniles in replicate dishes were first pooled together. One-way ANOVA results showing the effects of larval food treatment (fixed factor: Low and High) on percent survival, and increase in shell length and total organic carbon content of juveniles are shown in respective panels
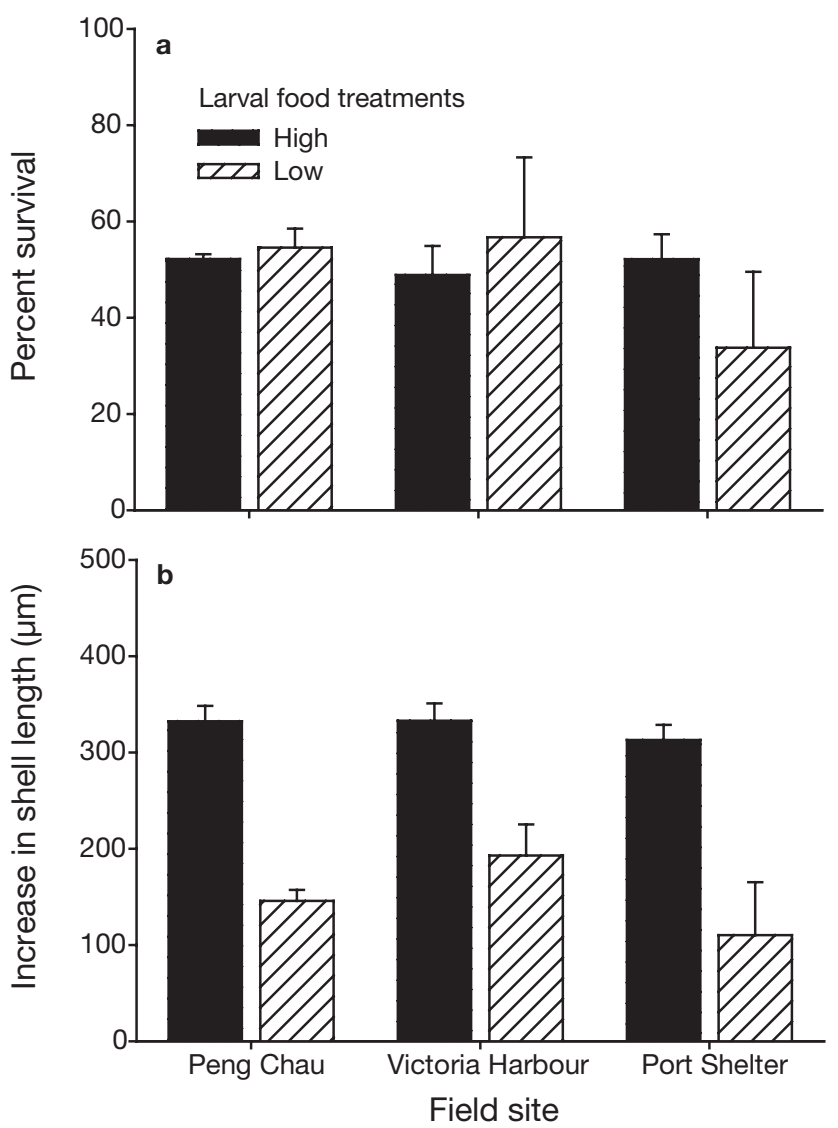

Fig. 4. Crepidula onyx. Expt II: (a) percent survival and (b) increase in shell length of juveniles at $6 \mathrm{~d}$ post-metamorphosis at Peng Chau, Victoria Harbour and Port Shelter; juveniles were developed from larvae from High and Low treatments. Data are mean $(+\mathrm{SD})$ of 3 replicate frames, each with 13 to 33 transplanted juveniles. In (b), increases in shell length of all juveniles ( 3 to 18 ) in replicate frames were first pooled together

Table 1. Crepidula onyx. Expt II: 2-way ANOVA showing effects of field site (fixed factor: Peng Chau, Victoria Harbour and Port Shelter), larval food treatment (fixed factor: Low and High) and their interaction on percent juvenile survival and increase in shell length of juveniles after $6 \mathrm{~d}$ post-metamorphosis. Increases in shell length were $\log (x)$ transformed before ANOVA

\begin{tabular}{|lrrrr|}
\hline Source of variation & df & MS & \multicolumn{1}{c|}{$F$} & $\mathrm{p}$ \\
\hline Percent survival & & & & \\
Site & 2 & 205 & 1.99 & 0.179 \\
Larval food & 1 & 33 & 0.33 & 0.579 \\
Site $\times$ Larval food & 12 & 287 & 2.79 & 0.101 \\
Error & 18 & 103 & & \\
Increase in shell length & & & & \\
Site & 2 & 0.037 & 3.05 & 0.085 \\
Larval food & 1 & 0.601 & 50.22 & $<0.001$ \\
Site $\times$ Larval food & 2 & 0.025 & 2.06 & 0.171 \\
Error & 12 & 0.120 & & \\
\hline
\end{tabular}




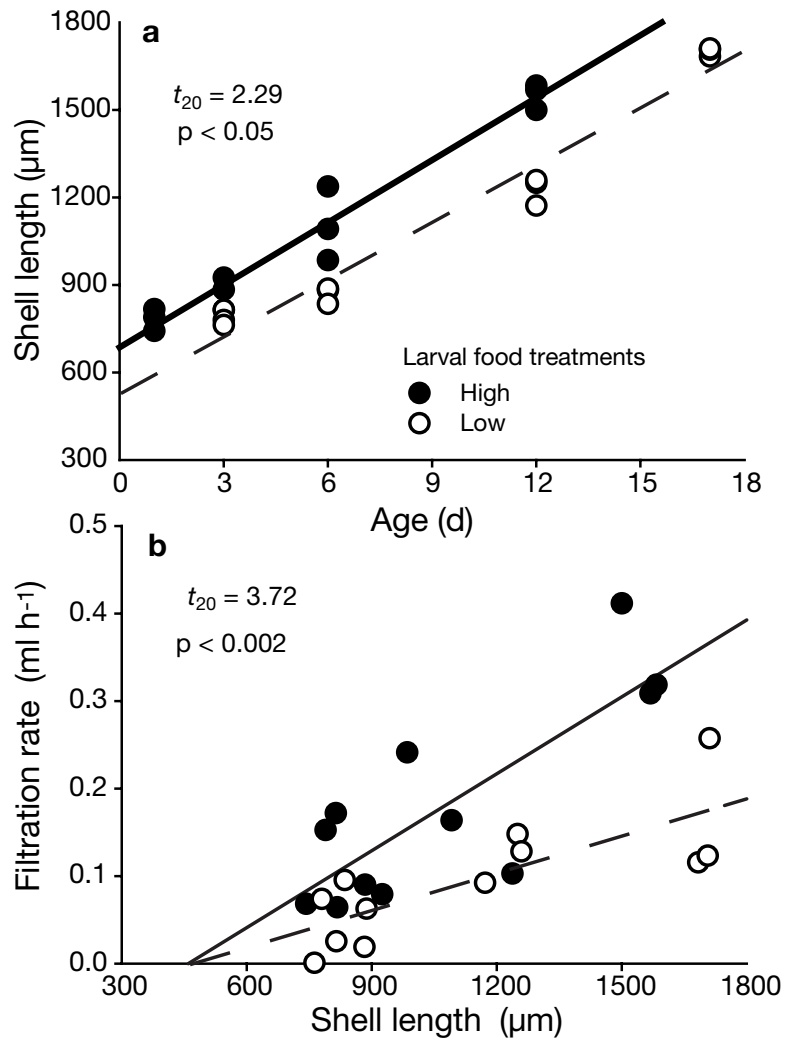

Fig. 5. Crepidula onyx. Expt III: (a) shell length and (b) filtration rates of juveniles from 1 to $12 \mathrm{~d}$ (High) or 3 to $17 \mathrm{~d}$ (Low) post-metamorphosis; juveniles were developed from larvae from High or Low treatments. Each data point represents a group of 8 to 42 juveniles feeding on Isochrysis galbana at a concentration of $2 \times 10^{5}$ cells ml $\mathrm{ml}^{-1}$ in a different replicate beaker. Solid lines: regression of High treatment: (a) juvenile shell length vs. juvenile age $\left(y=71.34 x+685.82, r^{2}=0.955\right.$, $\mathrm{p}<0.001)$; (b) filtration rate vs. juvenile shell length $(y=$ $0.000293 x-0.135, r^{2}=0.656, p=0.001$ ). Dashed lines: regression of Low treatment: (a) juvenile shell length vs. juvenile age $\left(y=65.56 x+522.45, \mathrm{r}^{2}=0.961, \mathrm{p}<0.001\right)$; (b) filtration rate vs. juvenile shell length $(y=0.000142 x-0.0675$, $\left.\mathrm{r}^{2}=0.603, \mathrm{p}=0.003\right)$. ANCOVA results comparing regressionline slopes of High and Low treatments are shown in respective panels

were observed. Furthermore, the larval food treatment had a significant effect on juvenile growth; the slopes of the regression lines for juveniles that had received different food concentrations as larvae were significantly different (Fig. 5a). The rate of increase in shell length was reduced for juveniles that had been exposed to the Low treatment.

At 3 and 6 d post-metamorphosis, the juveniles from the Low treatment had respective mean $( \pm \mathrm{SD})$ filtration rates of $0.033 \pm 0.037$ and $0.059 \pm 0.038 \mathrm{ml} \mathrm{h}^{-1}$ ( $\mathrm{n}=3$ ), which were slightly lesser than the respective means $( \pm \mathrm{SD})$ of $0.114 \pm 0.051$ and $0.170 \pm 0.069 \mathrm{ml} \mathrm{h}^{-1}$ $(\mathrm{n}=3)$ for juveniles from the High treatment $\left(t_{4}=2.215\right.$, $\mathrm{p}=0.091 ; t_{4}=2.408, \mathrm{p}=0.074$ ) (Fig 5b). At $12 \mathrm{~d}$ post- metamorphosis, the mean $( \pm \mathrm{SD})$ filtration rate of juveniles from the Low treatment was $0.123 \pm 0.028 \mathrm{ml} \mathrm{h}^{-1}$ $(\mathrm{n}=3)$ and was only one-third the mean $( \pm \mathrm{SD})$ of $0.346 \pm 0.057 \mathrm{ml} \mathrm{h}^{-1}(\mathrm{n}=3)$ of the juveniles from the High treatment $\left(t_{4}=6.113, \mathrm{p}=0.004\right)$. Positive linear relationships between juvenile shell length and filtration rates were observed. The slopes of the regression lines for juveniles that had received different treatments were significantly different: the rate of increase in filtration rate with body size was reduced for juveniles that experienced the Low treatment as larvae (Fig. 5b).

\section{DISCUSSION}

Our work shows that limiting food for the larvae of Crepidula onyx compromised both juvenile growth and survival in the laboratory, even though the juveniles were reared (for 3 to $12 \mathrm{~d}$ ) at optimal food concentration, similar to what has been found for sea urchin Strongylocentrotus purpuratus, mussel Mytilus galloprovincialis, barnacles Balanus amphitrite and B. glandula, and slipper limpet C. fornicata (Miller \& Emlet 1999, Pechenik et al. 2002, Phillips 2002, Thiyagarajan et al. 2003, Emlet \& Sadro 2006). The current study also suggests that poor juvenile food-collecting performance was at least partially responsible for the observed effects of limited larval food on reducing juvenile growth in $C$. onyx, see also results for $C$. fornicata juveniles by Pechenik et al. (2002). At 12 d postmetamorphosis, the filtration rate of juveniles developed from larvae reared under limited food conditions was only one-third that of their control counterparts. After taking juvenile size differences into account, our results still indicate that the mean filtration rate for juveniles developed from larvae reared under limited food conditions was always lower than that for their similarly sized control counterparts.

On the other hand, the results of the present study do not support the suggestion that juveniles reared with limited food as larvae might also have a reduced ability to assimilate food (Pechenik et al. 2002). Mean percent carbon retained in the Crepidula onyx juvenile body at $24 \mathrm{~h}$ was approximately $70 \%$; assimilation efficiencies of 60 to $95 \%$ appear typical for marine gastropods (reviewed by Pechenik 1979). Furthermore, these juveniles metamorphosed at a smaller size than those reared at the High treatment as larvae. If juvenile growth rate increases with juvenile size (Marshall \& Keough 2004), the juveniles of smaller sizes may have a time lag before reaching the size and growth rate of their counterparts at metamorphosis (Phillips 2002). This, however, does not seem able to fully explain the observed effects of limited larval food on 
reducing juvenile growth: when we compared the growth of similarly sized juveniles developed from the 2 larval food treatments, the effects of larval food on mean juvenile growth were still prominent.

In contrast to the results of the laboratory experiment, reducing food availability to larvae did not hamper juvenile survival in the field, although it still reduced mean juvenile growth rate. The results that we obtained for survival of juvenile Crepidula onyx in the field also differed from what was found for the mussel Mytilus galloprovincialis (Phillips 2002) and the barnacle Balanus glandula juveniles (Emlet \& Sadro 2006); in those studies, juvenile survival rates were reduced when larvae had been reared under limited food conditions. Indeed, there is always a question about how well laboratory-derived results can be extrapolated to the field, since laboratory conditions can never fully mimic the complexity of the natural environment (Todd \& Keough 1994) and are considered generally poor relative to field conditions in terms of food quality and light and flow regimes (Phillips 2002). It seems that juvenile habitat conditions can alter the effects of larval food on juvenile survival; the adverse effects of limited larval food on juvenile survival were compensated for by field conditions relative to laboratory conditions. Alternatively, mortality might be largely random if it is caused by salinity stress, heat stress, or predation to which juvenile vulnerability does not depend on juvenile size (Moran \& Emlet 2001).

The present study confirms previous reports that limited food availability during the larval stage can reduce the size, total organic content and energy reserves of newly metamorphosed juveniles (gastropods: Pechenik et al. 2002; bivalves: Phillips 2002, 2004; crustaceans: Thiyagarajan et al. 2003), but we did not determine if the newly metamorphosed juveniles of Crepidula onyx were energy depleted or not. Indeed, 'depletion of energy reserves' has been hypothesised as the mechanism through which latent effects are mediated (Marshall \& Keough 2006, reviewed by Pechenik 2006). Evidence was provided by an observed correlation between increased larval swimming activity, reduced energy content and reduced colony growth in the colonial ascidian Diplosoma listerianum (Marshall et al. 2003) and the bryozoan Bugula neritina (Wendt 1998). Furthermore, when the larvae of the facultatively lecithotrophic nudibranch gastropod Phestilla sibogae were raised without phytoplankton, an extended larval phase resulted in reduced juvenile weight, a longer juvenile period and lower reproductive output; such adverse effects of delayed metamorphosis on the nudibranch were not found when larvae were raised with phytoplankton (Miller 1993). Similarly, the negative effects of delayed metamorphosis for the bryozoan $B$. neritina were offset by larval access to dissolved organic matter (Wendt \& Johnson 2006), again suggesting a link between larval energy reserves and latent effects. Moreover, in the intertidal barnacle Semibalanus balanoides, the organic content of newly attached cyprids and juvenile growth potential varied temporally, suggesting that larval experience may be at work in affecting the quality of these new recruits and, subsequently, juvenile growth (Jarrett 2003). Such results clearly support the 'depletion of energy reserves' hypothesis, but they do not necessarily disprove other mechanisms through which latent effects are mediated (Phillips 2006).

Indeed, some data argue against the 'depletion of energy reserves' hypothesis. For example, the average larval size and lipid stores of a cohort were not related to the number of larvae recruiting to the population for the mussel Mytilus sp. (Phillips 2006). For the solitary sea squirt Styela plicata, although delaying metamorphosis depleted larval lipid reserves, no latent effects were observed in the newly metamorphosed juveniles (Thiyagarajan \& Qian 2003). Similarly, for the polychaete Capitelra sp. I, delaying metamorphosis had no effect on post-metamorphic growth rate, time to first reproductive activity, or fecundity (Pechenik \& Cerulli 1991). For the polychaete worm Hydroides elegans, delaying metamorphosis caused similarly poor juvenile performance whether the larvae had been fed or starved (Qian \& Pechenik 1998). These results indicate that depletion of energy reserves alone may not be causing the observed latent effects. In addition, $M$. galloprovincialis juveniles that had initially experienced the High treatment and switched to the Low treatment late in larval life had faster growth and lower mortality rates than those that had initially experienced the Low treatment and switched to the High treatment during larval life, but these juvenile mussels from the 2 treatments had similar sizes and lipid content (Phillips 2004). In addition, Pechenik et al. (2002) reported that average juvenile growth rates of Crepidula fornicata were not reduced when larvae were fed for $2 \mathrm{~d}$ before being starved, contrary to the results when larvae were starved beginning within $12 \mathrm{~h}$ of hatching. The timing of larval food limitation may have important consequences for juvenile performance. This suggests that larval nutritional stress can interfere with processes that take place or structures that develop very early in larval life, but that are important for later stages.

It remains unclear how food limitation during larval life might actually lead to the poor food-collecting performance of juveniles. Such poor food-collecting performance may reflect abnormal juvenile gill structure or function. However, the adverse effects of food limi- 
tation on juvenile growth were seen even when larvae were food limited very early in development, long before gills were formed (Pechenik et al. 2002, Phillips 2004). It has been suggested that food limitation during larval life might interfere with either the timing or the magnitude of transcriptional or translational processes associated with juvenile gill formation later in development (Pechenik et al. 2002, Pechenik 2006). Moreover, food limitation early in larval life could impact proper gill formation later on if the specific energy stores or materials to be used in gill formation are sequestered early in larval life (Pechenik 2006).

Although we have shown that poor food-collecting performance of juveniles probably accounts for the documented effects of limited larval food supply on the juvenile growth in Crepidula onyx, different mechanisms may be responsible for different aspects of juvenile performance and may vary among species and larval experiences. This is particularly true for marine invertebrates, since they have a wide range of larval development patterns, such as non-feeding vs. feeding terminal development stages, fixed developmental period vs. delayed metamorphosis, and predatory vs. filter-feeding lifestyles (Phillips 2002, Young 2002). Future studies should also consider a wider range of mechanisms through which latent effects associated with delayed metamorphosis, salinity stress and exposure to sub-lethal concentrations of pollutants are mediated.

Acknowledgements. This manuscript benefited greatly from the comments and suggestions of 3 anonymous reviewers. We wish to thank J. A. Pechenik (Tufts University) and S. C. K. Lau (National University of Singapore) for their advice on drafting this manuscript. We are also grateful to R. Zhang, K. Tam and F. Mok for kindly assisting in total organic carbon measurement and for technical support. This study was supported by the Area of Excellence Scheme of UGC (Project No. AoE/P-04/2004) and RGC grants (HKUST 6402/05M) to P.Y.Q.

\section{LITERATURE CITED}

Chiu JMY, Thiyagarajan V, Pechenik JA, Hung OS, Qian PY (2007) Influence of bacteria and diatoms in biofilms on metamorphosis of the marine slipper limpet Crepidula onyx. Mar Biol 151:1417-1431

Eckert GL (1995) A novel larval feeding strategy of the tropical sand dollar, Encope michelini (Agassiz): adaptation to food limitation and an evolutionary link between planktotrophy and lecithotrophy. J Exp Mar Biol Ecol 187: 103-128

Emlet RB, Sadro SS (2006) Linking stages of life history: how larval quality translates into juvenile performance for an intertidal barnacle (Balanus glandula). Integr Comp Biol 46:334-346

Gosselin LA, Qian PY (1997) Juvenile mortality in benthic marine invertebrates. Mar Ecol Prog Ser 146:265-282

Hart MW, Strathmann RR (1994) Functional consequences of phenotypic plasticity in echinoid larvae. Biol Bull (Woods Hole) 186:291-299

He X, Wang WX (2006) Releases of ingested phytoplankton carbon by Daphnia magna. Freshw Biol 51:649-665

His E, Seaman MNL (1992) Effects of temporary starvation on the survival, and on subsequent feeding and growth, of oyster (Crassostrea gigas) larvae. Mar Biol 114:277-279

Jarrett JN (2003) Seasonal variation in larval condition and postsettlement performance of the barnacle Semibalanus balanoides. Ecology 84:384-390

Mann R, Gallager SM (1985) Physiological and biochemical energetics of larvae of Teredo navalis L. and Bankia gouldi (Bartsch) (Bivalvia: Teredinidae). J Exp Mar Biol Ecol 85:211-228

Marsh AG, Leong PKK, Manaha DT (1999) Energy metabolism during embryonic development and larval growth of an Antarctic sea urchin. J Exp Biol 202:2041-2050

Marshall DJ, Keough MJ (2004) Variable effects of larval size on post-metamorphic performance in the field. Mar Ecol Prog Ser 279:73-80

Marshall DJ, Keough MJ (2006) Complex life cycles and offspring provisioning in marine invertebrates. Integr Comp Biol 46:643-651

Marshall DJ, Pechenik JA, Keough MJ (2003) Larval activity levels and delayed metamorphosis affect post-larval performance in the colonial ascidian Diplosoma listerianum. Mar Ecol Prog Ser 246:153-162

McEdward LR, Qian PY (2001) Effects of the duration and timing of starvation during larval life on the metamorphosis and initial juvenile size of the polychaete Hydroides elegans (Haswell). J Exp Mar Biol Ecol 261:185-197

Miller BA, Emlet RB (1999) Development of newly metamorphosed juvenile sea urchins (Strongylocentrotus franciscanus and S. purpuratus): morphology, the effects of temperature and larval food ration, and method for determining age. J Exp Mar Biol Ecol 253:67-90

Miller SE (1993) Larval period and its influence on post-larval life history: comparison of lecithotrophy and facultative planktotrophy in the aeolid nudibranch Phestilla sibogae. Mar Biol 117:635-645

Moran AL, Emlet RB (2001) Offspring size and performance in variable environments: field studies on a marine snail. Ecology 82:1597-1612

Pechenik JA (1979) Leakage of ingested carbon by gastropod larvae, and its effect on the calculation of assimilation efficiency. Estuaries 2:45-49

Pechenik JA (2006) Larval experience and latent effectsmetamorphosis is not a new beginning. Integr Comp Biol 46:323-333

Pechenik JA, Cerulli TR (1991) Influence of delayed metamorphosis on survival, growth, and reproduction of the marine polychaete Capitelra sp. I. J Exp Mar Biol Ecol 151:17-27

Pechenik JA, Jarrett JN, Rooney J (2002) Relationships between larval nutritional experience, larval growth rates, juvenile growth rates, and juvenile feeding rates in the prosobranch gastropod Crepidula fornicata. J Exp Mar Biol Ecol 280:63-78

Phillips NE (2002) Effects of nutrition-mediated larval condition on juvenile performance in a marine mussel. Ecology 83:2562-2572

Phillips NE (2004) Variable timing of larval food has consequences for early juvenile performance in a marine mussel. Ecology 85:2341-2346

Phillips NE (2006) Natural variability in size and condition at settlement of 3 species of marine invertebrates. Integr Comp Biol 46:598-604

Qian PY, Chia FS (1993) Larval development as influenced by 
food limitation in two polychaete worms, Capitella capitata and Polydora ligni Webster. J Exp Mar Biol Ecol 166: 93-105

Qian PY, Pechenik JA (1998) Effects of larval starvation and delayed metamorphosis on juvenile survival and growth of the tube-dwelling polychaete Hydroides elegans (Haswell). J Exp Mar Biol Ecol 227:169-185

Qiu JW, Qian PY (1997) Effects of food availability, larval source and culture method on larval development of Balanus amphitrite Darwin: implications for experimental design. J Exp Mar Biol Ecol 217:47-61

Thiyagarajan V, Qian PY (2003) Effects of temperature, salinity and delayed attachment on development of the solitary ascidian Styela plicata (Lesueur). J Exp Mar Biol Ecol 290: 133-146

Thiyagarajan V, Harder T, Qiu JW, Qian PY (2003) Energy content at metamorphosis and growth rate of the juvenile barnacle Balanus amphitrite. Mar Biol 143:543-554

Todd CD, Keough MJ (1994) Larval settlement in hard sub-

Editorial responsibility: Howard Browman (Associate Editorin-Chief), Storebø, Norway stratum epifaunal assemblages: a manipulative field study of the effects of substratum filming and the presence of incumbents. J Exp Mar Biol Ecol 181:159-187

Thorson G (1950) Reproductive and larval ecology of marine bottom invertebrates. Biol Rev 25:1-45

Wendt DE (1998) Effect of larval swimming duration on growth and reproduction of Bugula neritina (Bryozoa) under field conditions. Biol Bull (Woods Hole) 195:126-135

Wendt DE, Johnson CH (2006) Using latent effects to determine the ecological importance of dissolved organic matter to marine invertebrates. Integr Comp Biol 46:634-642

Young CM (2002) A brief history and some fundamentals. In: Young CM (ed) Atlas of marine invertebrate larvae. Academic Press, San Diego, CA, p 1-20

Zar JH (1999) Biostatistical analysis, 4th edn. Prentice Hall, Englewood Cliffs, NJ

Zhao B, Qiu JW, Qian PY (2003) Effects of food availability on larval development in the slipper limpet Crepidula onyx (Sowerby). J Exp Mar Biol Ecol 294:219-233

Submitted: November 17, 2006; Accepted: February 16, 2007 Proofs received from author(s): July 10, 2007 